\title{
Change of Various Characteristics between Spawning and Non-spawning Season in Diploid and Induced Triploid Far Eastern Catfish, Silurus asotus
}

\author{
Sun Young Lim, Hyun Woo Gil and In-Seok Park \\ Division of Marine Bioscience, College of Ocean Science and Technology, Korea Maritime and Ocean University, \\ Busan 49112, Korea
}

\begin{abstract}
The purpose of this study is to investigate the differences fatty acids and hormonal parameters in the spawning and non-spawning season between the diploid and induced triploid Far Eastern catfish, Silurus asotus. The measured triploids were produced by cold shock for $50 \mathrm{~min}$ at $4^{\circ} \mathrm{C}$ in May 2014, the spawning season of diploid was in May, and the nonspawning season was designated in January. Estradiol and testosterone and gonadosomatic index of diploid were higher than those of induced triploid in spawning season $(P<0.05)$, and those of diploid in spawning season were higher than nonspawning season. On the other hand, thyroid stimulating hormone and thyroxine of induced triploid were higher than those of diploid in spawning season $(P<0.05)$. Erythrocyte count of diploid was higher than that of induced triploid in spawning season and non-spawning seasons. Mean corpuscular volume and mean corpuscular hemoglobin of induced triploid were higher than those of diploid in both seasons $(P<0.05)$. Percentages of total saturated fatty acids and n-3 polyunsaturated fatty acids of induced triploid were higher than those of diploid in spawning season, but those of diploid were higher in non-spawning season $(P<0.05)$. Percentages of total mono unsaturated fatty acids and total $\mathrm{n}-6$ polyunsaturated fatty acids of diploid were higher than those of induced triploids in spawning season, while those of induced triploid in non-spawning season were higher $(P<0.05)$. Therefore, induced triploids in the spawning season tend to concentrate on growth and lipid-synthesization, whereas, diploids concentrate on reproduction and gonadal maturation rather than on growth. In non-spawning season, growth and lipid-synthesization were not significantly different between diploid and induced triploid.
\end{abstract}

Key words : Far Eastern catfish, Hematological parameter, Sex hormone, Thyroid hormone

\section{INTRODUCTION}

Far Eastern catfish, Silurus asotus belonging to Siluridae, Siluriformes are distributed in Korea's all rivers, Japan, China, and Taiwan (Chyung, 1996). Far Eastern catfish, in addition to the channel catfish, Ictalurus punctatus has been aquaculture in Korea. The aquaculture production of Far Eastern catfish in Korea was 4,267 tons at
2015, and increasing gradually until now. Far Eastern catfish has good taste than the channel catfish is that increasingly popular in the spotlight to consumers (Yu et al., 2009; Yang et al., 2015).

The induction of triploidy has been achieved in a number of different freshwater and marine fish species (Thorgaard, 1983; Benfey, 1989; Ihssen et al., 1990). Induced triploid was not normal gonad development in spawning

\footnotetext{
Manuscript received September 14, 2017, Received in revised form September 18, 2017, Accepted September 22, 2017

$\dagger$ Corresponding Author : In-Seok Park, Division of Marine Bioscience, College of Ocean Science and Technology, Korea Maritime and Ocean University, Busan 49112, Korea. Tel : +82-51-410-4321, Fax : +82-51-404-4750, E-mail : ispark@kmou.ac.kr

This is an Open Access article distributed under the terms of the Creative Commons Attribution Non-Commercial License (http:// creativecommons.org/licenses/by-nc/3.0) which permits unrestricted non-commercial use, distribution, and reproduction in any medium, provided the original work is properly cited.
} 
season (Lincoln \& Scott, 1984). Gonadosomatic index (GSI) of induced triploid was also very low, and induced triploid was produced a heteroploid gamete. Therefore induced triploid became functionally sterile (Thorgaard, 1983; Lincoln \& Scott, 1984; Kim et al., 2001; Gil et al., 2016). Because induced triploid sterile, to convert the energy used in the reproductive growth of the body. Growth is continued as compared to diploid in the spawning season (Ihssen et al., 1990; Kim et al., 1990). Infertility allows organism to avoid the metabolic costs of sexual maturation, result in continued somatic growth in induced triploid fish, with maintenance of flesh quality during the period when diploids sexually mature (Seol et al., 2008). Induced triploid grew significantly faster than diploid from the same spawns, reared under similar culture conditions (Qin et al., 1998). Induced triploid the cell size is increased, but decreased the number of cell in body. So induced triploid doesn't cause gigantism (Beatty \& Fischberg, 1951).

Study on the production and induction of triploid has been many but infertility triploid and diploid studies were doesn't enough either. The purpose of our study was to investigate difference between diploid and induced triploid in hormones of spawning season and non-spawning season.

\section{MATERIALS AND METHODS}

For production of induced triploid Far Eastern catfish, Silurus asotus eggs were cold shocked at $4{ }^{\circ} \mathrm{C}$ during 60 minutes at 5 minutes after fertilized for retaining the second polar body (Kim et al., 2001) in May 2014 and induced triploidy juvenile were determined at October 2012 using flowcytometry (Partec, DE / PA, Germany).

In this study using 2 years broodstock raised in recirculating water tank in Fishery Genetics and Breeding Sciences Laboratory, Korea Maritime and Ocean University, Korea. The mean body length was $45.2 \pm 3.28 \mathrm{~cm}$, and mean body weight was $368 \pm 31.4$ g, respectively. For determine difference of all measurements between spawning and non-spawning season, water temperature of each group were changed by seasonal temperature variation. Fluorescent light was at 1,000 lux and the light was on from 6:00 to 18:00. All measurements for spawning season were measured in May and non-spawning season was measured in January, 2016, respectively.

Change in water temperature was measured during the experimental period (Fig. 1). Water temperature during the spawning season was $25 \pm 1.0^{\circ} \mathrm{C}$, and during non-spawning season it was $13.5 \pm 4.64^{\circ} \mathrm{C}$. The mean value of water temperature was $22.4 \pm 4.58^{\circ} \mathrm{C}$ (Fig. 1). Commercial feed (Cheonhajeil Feed Coporation, Korea) was used an experimental diet. Nutritional composition of the feed was as follows; the contents of crude protein, crude fat and crude fiber were 40,5 and $5 \%$, and ash, calcium, phosphorus, mineral premix and vitamin premix were contained $14,1,1,1$ and $1 \%$ in experimental diet.

The 30 samples of the diploid and 30 samples of the induced triploid were measured in the spawning season and non-spawning season, respectively. In the non-spawning season measured each the 30 samples of the diploid and 30 samples of the induced triploid. Gonadosomatic index (GSI) was measured by following equation: (gonad weight/body weight $) \times 100$. To measure the concentrations of estradiol$17(\beta)$ and testosterone, draw a $75 \mathrm{uL}$ of serum and add it to the detector buffer. Next, mix a specimen with buffer by voltex mixer and leave to the specimen at room temperature for $15 \mathrm{~min}$, finally, insert it to the i-Chroma reader.

To investigate changes in growth hormone levels, the concentrations of thyroid stimulating hormone (TSH) and thyroxine (T4) in samples of each group were measured using fluorophotometry during the 12 months following hatching. To measure the concentrations of TSH and T4, draw a $10 \mu \mathrm{L}$ of serum and add it to the detector buffer. Next, mix a specimen with buffer by voltex mixer and leave to the specimen at room temperature for $10 \mathrm{~min}$, finally, insert it to the i-Chroma reader. Cholesterols and insulin were measured by fluorophotometry (i-Chroma, 


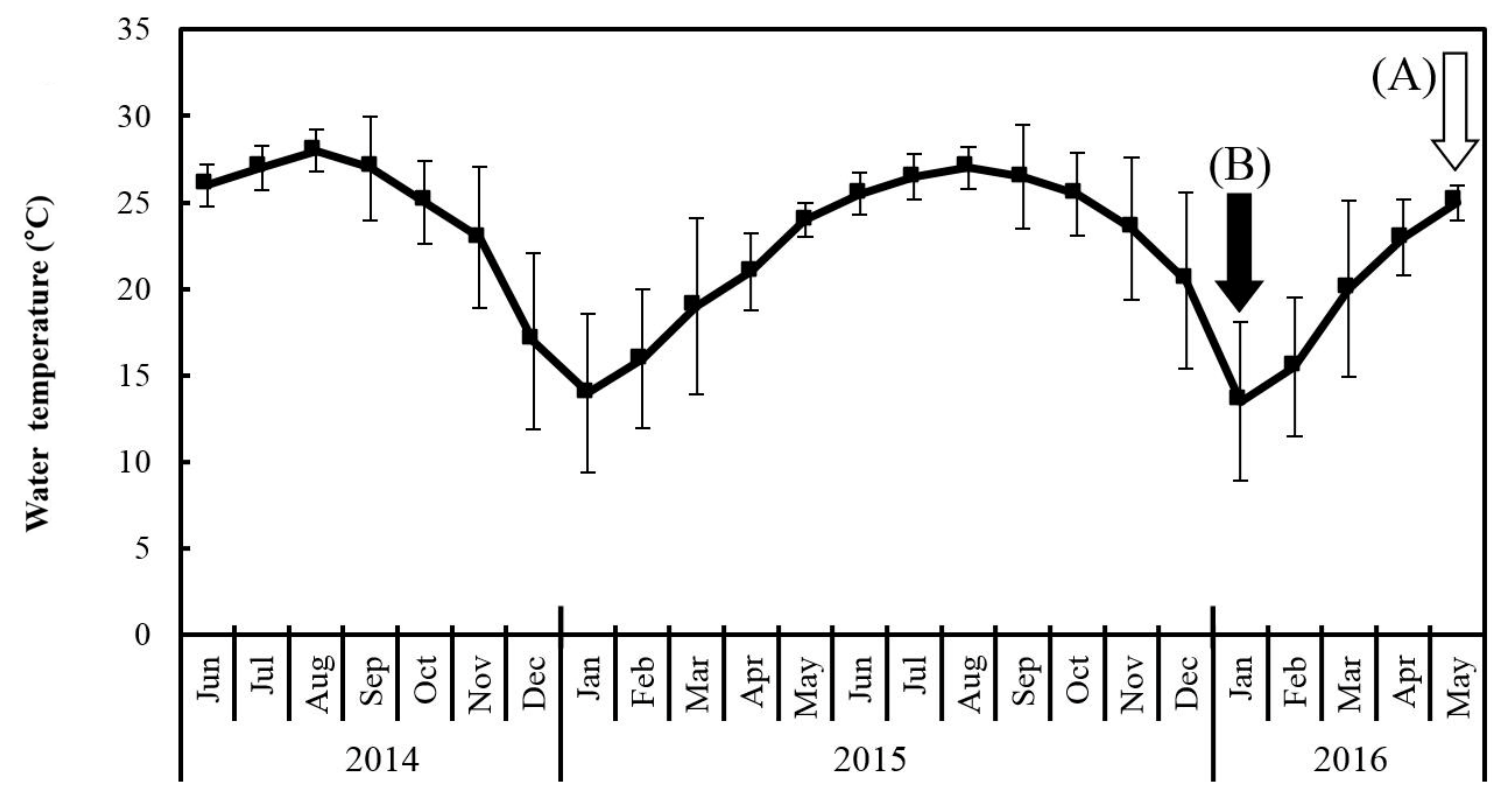

Experimental period

Fig. 1. Change of water temperature in Far Eastern catfish Silurus asotus while experimental period. The arrows on vertical bars are sampling period for diploid and induced triploid Far Eastern catfish at non-spawning season (A; white arrow, January 2016) and spawning season (B; black arrow, May 2016), 2016, respectively. The values of vertical bars are standard deviation while 30 days of each month.

Sun Kyung Medical, Korea). Blood analysis was measured by autohematology analyzer (PE-6800, Prokan, China).

Fatty acids was measured by injecting the gas chromatograpphy the purified fatty acids in forch method. Fatty acid methyl ester was prepared with $14 \% \mathrm{BF}_{3} /$ methanol and analyzed with a gas chromatograph (CP-3380, Varian Inc., Palo Alto, CA, USA) using a flame-ionization detector, as described previously (Salem et al., 1996). The chromatography utilized a CP-SIL 5 CB fused silica capillary column $(60 \mathrm{~m}$ length $\times 0.32 \mathrm{~mm}$ i.d. film thickness $0.01 \mu \mathrm{m}$, Varian Inc., Palo Alto, CA, USA). Peaks were identified by comparison with fatty acid standards (GLC462, Nu-Check-Prep, Elysian, MN, USA), and area and its percentage for each resolved peak were analyzed using a Galaxie chromatography software.

Two-way ANOVA and Duncan's multiple range test (Duncan, 1955) were used to analyze the significance of the difference among the means of treatments through SPSS software (SPSS 9.0, SPSS Inc., USA).

\section{RESULTS AND DISCUSSION}

Table 1 shows the results of two-way ANOVA test on Gonadosomatic index (GSI), sex hormone, thyroid hormone, and hematological parameter between diploid and induced triploid Far Eastern catfish, Silurus asotus during the spawning and non-spawning seasons. Body weight (BW), subcutaneous fat weight/BW (FW), GSI, estradiol and testosterone were significantly affected by season and ploidy $(P<$ $0.05)$. Thyroid stimulating hormone (TSH) and thyroxine were affected by ploid, and induced triploid was relatively higher than diploid, but there was a difference only in spawning season $(P<0.05)$. In addition, significant interactions of season and ploidy on BW, FW and GSI were observed.

As shown in Table 1, GSI values of induced triploid Far 
Table 1. Comparative analysis of gonadosomatic index (GSI), sex hormone and thyroid hormone between diploid (2n) and induced triploid (3n) Far Eastern catfish, Silurus asotus in spawning and non-spawning season ${ }^{1}$

\begin{tabular}{|c|c|c|c|c|c|c|c|}
\hline & \multicolumn{2}{|c|}{ Spawning $^{2}$} & \multicolumn{2}{|c|}{ Non-spawning ${ }^{2}$} & \multicolumn{3}{|c|}{ Two-way ANOVA test } \\
\hline & $2 n$ & $3 n$ & $2 n$ & $3 n$ & Season & Ploidy & Interaction \\
\hline $\begin{array}{l}\text { Body weight } \\
(\mathrm{BW}, \mathrm{g})\end{array}$ & $324.1 \pm 6.88^{b}$ & $904.2 \pm 9.17^{\mathrm{d}}$ & $309.8 \pm 7.41^{\mathrm{a}}$ & $894.3 \pm 8.54^{\mathrm{c}}$ & $P<0.05$ & $P<0.05$ & $P<0.05$ \\
\hline $\begin{array}{l}\text { Subcutaneous fat } \\
\text { weight/BW (\%) }\end{array}$ & $4.7 \pm 0.54^{\mathrm{a}}$ & $16.5 \pm 1.02^{\mathrm{c}}$ & $8.9 \pm 0.77^{\mathrm{b}}$ & $16.6 \pm 1.06^{\mathrm{c}}$ & $P<0.04$ & $P<0.03$ & $P<0.04$ \\
\hline GSI $(\%)^{3}$ & $11.4 \pm 1.55^{\mathrm{c}}$ & $0.1 \pm 0.02^{\mathrm{a}}$ & $6.4 \pm 1.01^{\mathrm{b}}$ & $0.1 \pm 0.02^{\mathrm{a}}$ & $P<0.05$ & $P<0.04$ & $P<0.05$ \\
\hline Estradiol (pg/L) & $75.1 \pm 8.67^{\mathrm{c}}$ & $8.6 \pm 1.43^{\mathrm{a}}$ & $10.1 \pm 1.88^{\mathrm{b}}$ & $8.6 \pm 1.43^{\mathrm{a}}$ & $P<0.04$ & $P<0.04$ & $P<0.14$ \\
\hline Testosterone (ng/L) & $8.3 \pm 1.36^{\mathrm{c}}$ & $1.9 \pm 0.15^{\mathrm{a}}$ & $2.3 \pm 0.13^{\mathrm{b}}$ & $1.9 \pm 0.15^{\mathrm{a}}$ & $P<0.04$ & $P<0.05$ & $P<0.11$ \\
\hline $\begin{array}{l}\text { Thyroid stimulating } \\
\text { hormone }(\mu \mathrm{IU} / \mathrm{L})\end{array}$ & $2.5 \pm 0.38^{\mathrm{a}}$ & $3.9 \pm 0.52^{b}$ & $3.7 \pm 0.44^{\mathrm{b}}$ & $3.8 \pm 0.92^{b}$ & $P<0.08$ & $P<0.01$ & $P<0.10$ \\
\hline Thyroxine $(\mu \mathrm{g} / \mathrm{dL})$ & $7.9 \pm 1.12^{\mathrm{a}}$ & $11.4 \pm 1.24^{\mathrm{b}}$ & $11.5 \pm 1.39^{\mathrm{b}}$ & $11.3 \pm 1.71^{\mathrm{b}}$ & $P<0.06$ & $P<0.01$ & $P<0.12$ \\
\hline
\end{tabular}

${ }^{1}$ Values of each group were mean \pm standard error. Values in the same column not sharing common superscripts are significantly different among ploidy and season $(P<0.05)$.

${ }^{2}$ All parameters of each group were measured in May, 2016 for spawning season and January, 2016 for non-spwaning season, respectively.

${ }^{3}$ Gonadosomatic index $(\mathrm{GSI})=($ Gonad weight/Body weight $) \times 100$.

Eastern catfish were less than those of diploid both spawning season and non-spawning season $(P<0.05)$. In addition, gonads of induced triploid were infertility (Fig. 2), and GSI of induced triploid in spawning season and nonspawning season were not significantly different from each other $(P>0.05)$. GSI of diploid in the spawning season were significantly higher than that the non-spawning season $(P<0.05)$. In induced triploid group, estradiol and testosterone were not significantly different between spawning and non-spawning season $(P>0.05)$, but in diploid, the values of two hormones in spawning season were significantly higher than those in non-spawning season $(P<0.05)$. During experimental period, estradiol and testosterone of diploid were significantly higher than those of induced triploid $(P<0.05)$. In spawning season, TSH and thyroxine of induced triploid were significantly higher than those of diploid $(P<0.05)$, but in non-spawning season, two hormones were not significantly different between diploid and induced triploid, respectively $(P>0.05)$.

As shown in Table 1, estradiol and testosterone of diploid during the non-spawning season were shown to be higher compared to the spawning season $(P<0.05)$. Testosterone and estradiol of induced triploid Far Eastern catfish were not significantly different between the spawning season and non-spawning season, respectively $(P>0.05)$. The difference in sex hormones was observed in diploid during the spawning season and the non-spawning season, but the difference was not observed in the induced triploid $(P<$ 0.05). The followings were observed: initial survival of freshwater fish, transformation, and the effect of thyroxine on the development and growth (Donaldson et al., 1979; Lam \& Sharma, 1985; Weatherley \& Gill, 1987). Thy 


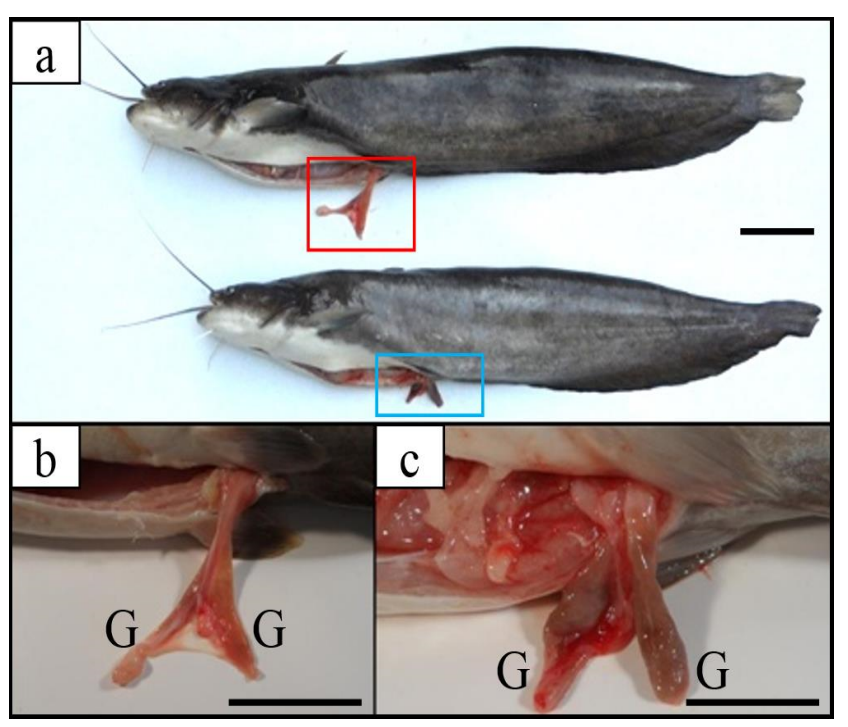

Fig. 2. Pictures of external morphology and gonad in induced triploid Far Eastern catfish Silurus asotus. a: external morphology and gonad of induced triploid; b: high power views of red line boxes in Fig. 2-a; C: high power views of blue line boxes in Fig. 2-a. G: gonad. Scale bars indicate $5 \mathrm{~cm}$. roxine was observed to be higher in induced triploid during the spawning season $(P<0.05)$. Induced triploids can be expected to show better growth compared to the diploid. In diploid, thyroxine is increased during non-spawning season than during the spawning season.

As shown in Table 2, erythrocyte count, mean corpuscular volume (MCV), and mean corpuscular hemoglobin $(\mathrm{MCH})$ were significantly affected by ploidy $(P<0.05)$, but not by season $(P>0.05)$. Hematocrit, Total hemoglobin content, Mean corpuscular hemoglobin concentration (MCHC) were not significantly affected by season and ploidy $(P>$ 0.05). Significant interactions of season and ploidy were not observed on all hematological parameters. During spawning and non-spawning seasons, erythrocyte count of induced triploid Far Eastern catfish was less than that of diploid $(P<0.05)$, and hematocrit of induced triploid was lower than diploid $(P<0.05)$. In spawning and nonspawning seasons, MCVs of induced triploid was observed

Table 2. Comparative analysis of hematological parameters between diploid (2n) and induced triploid (3n) Far Eastern catfish, Silurus asotus in spawning and non-spawning season ${ }^{1}$

\begin{tabular}{|c|c|c|c|c|c|c|c|}
\hline \multirow{2}{*}{$\begin{array}{l}\text { Hematological } \\
\text { parameters }\end{array}$} & \multicolumn{2}{|c|}{ Spawning $^{2}$} & \multicolumn{2}{|c|}{ Non-spawning ${ }^{2}$} & \multicolumn{3}{|c|}{ Two-way ANOVA test } \\
\hline & $2 n$ & $3 n$ & $2 n$ & $3 n$ & Season & Ploidy & Interaction \\
\hline Erythrocyte count (cells $/ \mu \mathrm{L}$ ) & $2.5 \pm 0.24^{\mathrm{b}}$ & $1.2 \pm 0.06^{\mathrm{a}}$ & $2.6 \pm 0.38^{b}$ & $1.2 \pm 0.11^{\mathrm{a}}$ & $P<0.09$ & $P<0.01$ & $P<0.11$ \\
\hline Hematocrit (\%) & $35.7 \pm 3.18^{b}$ & $33.7 \pm 2.64^{\mathrm{a}}$ & $35.5 \pm 3.28^{\mathrm{b}}$ & $34.9 \pm 2.87^{\mathrm{ab}}$ & $P<0.13$ & $P<0.11$ & $P<0.12$ \\
\hline $\begin{array}{l}\text { Mean corpuscular } \\
\text { volume }\left(\mu \mathrm{m}^{3}\right)\end{array}$ & $139.3 \pm 5.42^{\mathrm{a}}$ & $204.0 \pm 4.46^{\mathrm{b}}$ & $140.8 \pm 6.91^{\mathrm{a}}$ & $204.2 \pm 5.73^{b}$ & $P<0.14$ & $P<0.03$ & $P<0.10$ \\
\hline $\begin{array}{l}\text { Total hemoglobin } \\
\text { content }(\mathrm{g} / 100 \mathrm{~mL})\end{array}$ & $9.3 \pm 0.83^{\mathrm{a}}$ & $9.4 \pm 0.35^{\mathrm{a}}$ & $9.3 \pm 0.83^{\mathrm{a}}$ & $9.4 \pm 0.35^{\mathrm{a}}$ & $P<0.10$ & $P<0.09$ & $P<0.14$ \\
\hline $\begin{array}{l}\text { Mean corpuscular hemo- } \\
\text { globin }(\mathrm{pg})\end{array}$ & $36.5 \pm 2.98^{\mathrm{a}}$ & $55.5 \pm 0.67^{\mathrm{b}}$ & $37.1 \pm 3.69^{\mathrm{a}}$ & $54.9 \pm 1.87^{\mathrm{b}}$ & $P<0.08$ & $P<0.01$ & $P<0.14$ \\
\hline $\begin{array}{l}\text { Mean corpuscular hemo- } \\
\text { globin concentration (\%) }\end{array}$ & $26.6 \pm 1.83^{\mathrm{a}}$ & $26.1 \pm 2.89^{\mathrm{a}}$ & $26.4 \pm 1.24^{\mathrm{a}}$ & $25.9 \pm 1.42^{\mathrm{a}}$ & $P<0.09$ & $P<0.08$ & $P<0.20$ \\
\hline
\end{tabular}

${ }^{1}$ Values of each group were mean \pm standard error. Values in the same column not sharing common superscripts are significantly different among ploidy and season $(P<0.05)$.

${ }^{2}$ All parameters of each group were measured in May, 2016 for spawning season and January, 2016 for non-spwaning season, respectively. 
to be larger than diploid, and $\mathrm{MCH}$ of induced triploid was larger than diploid during both seasons, however $\mathrm{MCHC}$ were not significantly different between diploid and induced triploid. Total blood hemoglobin level can influence aerobic capacity, and it is important for respiratory physiology and aerobic capacity (Benfey, 1999). As shown in Table 2, induced triploid showed increased haploid and enhanced cell size, but the cell number was decreased; and induced triploid Far Eastern catfish did not increase in body size. Park and Kim (2000), Kim et al. (2001) and Seol et al. (2008) suggested that giantism of induced triploid did not appear due to the decreasing cell number of induced triploid. In a previous study by Seol et al. (2008), erythrocyte count of diploid was higher than the induced triploid number. In the case of induced triploid Far Eastern catfish, the nucleus of the red blood cell has major axis which is 1.33 times larger and the minor axis is 1.26 times larger than the diploid (Seol et al., 2008). This fact is well accepted, and the measure of erythrocyte size is frequently used as the sole criterion for determining ploidy level in a fish (Benfey, 1999). Ojolick et al. (1995) clearly showed that induced triploid rainbow trout, Oncorhynchus mykiss has increased mortality rate, compared to diploids, when reared at chronic high temperatures where oxygen solubility is reduced and oxygen demand is increased.

Table 3 shows the significant difference in fatty acid between diploid and induced triploid Far Eastern catfish, during the spawning and non-spawning seasons. Fatty acid 14:0, palmitic acid (16:0), stearic acid (18:0), 22:0 and total saturated fatty acids (total SFA) were shown to be significant between diploid and induced triploid; and 14:0, 16:0, 18:0, and 20:0 were shown to be significant between the spawning and non-spawning seasons, respectively. The 14:0, 16:0, and 18:0 showed interaction between ploidy and season. The 16:1n-7, 18:1n-9, and total mono unsaturated fatty acids (total MUFA) showed significant difference between diploid and induced triploid. The 18:1n-9 and MUFA showed significant difference between the spawning and non-spawning seasons, and interaction was shown between ploidy and season, respectively. Total n-6 polyunsaturated fatty acids (total n-6 PUFA), 22:5n-3, 22:6n-3 and total n-3 polyunsaturated fatty acids (total n-3 PUFA) showed significant difference between diploid and induced triploid, respectively. The 18:2n-6, total n-6 PUFA, 22:5n-3, 22:6n-3 and total n-3 PUFA showed significant difference between the spawning and non-spawning seasons, and interaction was shown between ploidy and season, respectively.

Spawning and non-spawning variations by ploidy in flesh fatty acid composition are shown in Table 4. In general, the fatty acid profiles exhibited notable similarities in both diploid and induced triploid Far Eastern catfish at spawning and non-spawning. In the case of spawning, there were significant differences in percentages of total SFA, total n-6 PUFA and total n-3 PUFA between diploid and induced triploid $(P<0.05)$. SFA was mainly comprised of 16:0 and 18:0. Induced triploid showed higher percentages of 16:0 and 18:0, compared to diploid. The most commonly occurring MUFA were 16:1n-7 and 18:1n-9. The percentage of 18:1n-9 was lower while the percentage of $16: 1 \mathrm{n}-7$ was higher in induced triploid $(P<0.05)$. Among PUFA, induced triploid showed lower percentage of 18:2n- 6 and higher percentages of 22:5n-3 and 22:6n-3 $(P<0.05)$. In the case of non-spawning, there were significant differences in the percentages of total SFA, total MUFA, total n-6 PUFA and total n-3 PUFA between diploid and induced triploid $(P<0.05)$. However in spawning, induced triploid showed lower percentages of 16:0 and 18:0 and higher percentage of 18:1n-9, compared to diploid $(P<0.05)$. Among PUFA, induced triploid showed higher percentage of $22: 5 n-3$ and lower percentage of 22:6n-3 $(P<0.05)$.

Shirai et al. (2001) investigated the influence of spawning and season on lipid content, lipid classes, and fatty acid composition, and found that the percentages of 22:6n-3 in phosphatidylcholine and phosphatidylethanolamine from 
Table 3. Significances of fatty acid between diploid and induced triploid Far Eastern catfish, Silurus asotus in spawning and non-spawning season

\begin{tabular}{|c|c|c|c|}
\hline \multirow{2}{*}{ Fatty acid } & \multicolumn{3}{|c|}{ Two-way ANOVA test } \\
\hline & Ploidy & Season & Interaction \\
\hline $\mathrm{C} 14: 0$ & $P<0.01$ & $P<0.03$ & $P<0.05$ \\
\hline $\mathrm{C} 16: 0$ & $P<0.01$ & $P<0.02$ & $P<0.04$ \\
\hline C18:0 & $P<0.02$ & $P<0.02$ & $P<0.05$ \\
\hline $\mathrm{C} 20: 0$ & $P<0.11$ & $P<0.05$ & $P<0.13$ \\
\hline $\mathrm{C} 22: 0$ & $P<0.05$ & $P<0.13$ & $P<0.08$ \\
\hline $\mathrm{C} 24: 0$ & $P<0.11$ & $P<0.09$ & $P<0.13$ \\
\hline Total sat. ${ }^{1}$ & $P<0.04$ & $P<0.09$ & $P<0.07$ \\
\hline $\mathrm{C} 16: 1 \mathrm{n}-7$ & $P<0.05$ & $P<0.06$ & $P<0.07$ \\
\hline C18:1n-9 & $P<0.05$ & $P<0.05$ & $P<0.05$ \\
\hline $\mathrm{C} 18: 1 \mathrm{n}-7$ & $P<0.08$ & $P<0.09$ & $P<0.09$ \\
\hline C20:1n-9 & $P<0.11$ & $P<0.12$ & $P<0.22$ \\
\hline C22:1n-9 & $P<0.10$ & $P<0.09$ & $P<0.22$ \\
\hline $\mathrm{C} 24: 1 \mathrm{n}-9$ & $P<0.16$ & $P<0.17$ & $P<0.14$ \\
\hline Total mono. ${ }^{2}$ & $P<0.02$ & $P<0.04$ & $P<0.05$ \\
\hline $\mathrm{C} 18: 2 \mathrm{n}-6$ & $P<0.01$ & $P<0.02$ & $P<0.04$ \\
\hline C18:3n-6 & $P<0.12$ & $P<0.11$ & $P<0.12$ \\
\hline $\mathrm{C} 20: 2 \mathrm{n}-6$ & $P<0.12$ & $P<0.12$ & $P<0.13$ \\
\hline C20:3n-6 & $P<0.15$ & $P<0.16$ & $P<0.14$ \\
\hline$C 20: 4 n-6$ & $P<0.13$ & $P<0.16$ & $P<0.19$ \\
\hline $\mathrm{C} 22: 2 \mathrm{n}-6$ & $P<0.10$ & $P<0.11$ & $P<0.15$ \\
\hline$C 22: 4 n-6$ & $P<0.10$ & $P<0.10$ & $P<0.17$ \\
\hline $\mathrm{C} 22: 5 \mathrm{n}-6$ & - & - & - \\
\hline Total $n-6^{3}$ & $P<0.05$ & $P<0.05$ & $P<0.05$ \\
\hline C18:3n-3 & $P<0.11$ & $P<0.13$ & $P<0.11$ \\
\hline$C 20: 3 n-3$ & $P<0.12$ & $P<0.11$ & $P<0.13$ \\
\hline $\mathrm{C} 20: 5 n-3$ & $P<0.12$ & $P<0.13$ & $P<0.14$ \\
\hline$C 22: 5 n-3$ & $P<0.01$ & $P<0.04$ & $P<0.05$ \\
\hline $\mathrm{C} 22: 6 n-3$ & $P<0.01$ & $P<0.02$ & $P<0.04$ \\
\hline Total n-3 & $P<0.01$ & $P<0.02$ & $P<0.03$ \\
\hline
\end{tabular}

${ }^{1}$ Total saturated fatty acids.

${ }^{2}$ Total monounsaturated fatty acids.

${ }^{3}$ Total n-6 polyunsaturated fatty acids.

${ }^{4}$ Total n-3 polyunsaturated fatty acids. 
Table 4. Comparative analysis of fatty acid between diploid (2n) and induced triploid (3n) Far Eastern catfish, Silurus asotus in spawning and non-spawning season ${ }^{1}$

\begin{tabular}{|c|c|c|c|c|}
\hline \multirow{2}{*}{ Fatty acid } & \multicolumn{2}{|c|}{ Spawning $^{2}$} & \multicolumn{2}{|c|}{ Non-spawning ${ }^{2}$} \\
\hline & $2 n$ & $3 n$ & $2 n$ & $3 n$ \\
\hline C14:0 & $3.2 \pm 0.2^{\mathrm{a}}$ & $3.6 \pm 0.41^{\mathrm{a}}$ & $4.3 \pm 0.63^{b}$ & $5.2 \pm 0.30^{\mathrm{c}}$ \\
\hline $\mathrm{C} 16: 0$ & $18.4 \pm 0.49^{b}$ & $16.2 \pm 0.79^{\mathrm{a}}$ & $24.2 \pm 0.97^{\mathrm{d}}$ & $21.3 \pm 0.77^{\mathrm{c}}$ \\
\hline C18:0 & $8.8 \pm 2.15^{\mathrm{b}}$ & $11.7 \pm 0.07^{\mathrm{c}}$ & $7.9 \pm 0.58^{\mathrm{b}}$ & $6.3 \pm 0.18^{\mathrm{a}}$ \\
\hline $\mathrm{C} 20: 0$ & $4.1 \pm 0.12^{\mathrm{b}}$ & $4.3 \pm 0.12^{\mathrm{b}}$ & $2.8 \pm 0.90^{\mathrm{a}}$ & $2.8 \pm 0.27^{\mathrm{a}}$ \\
\hline $\mathrm{C} 22: 0$ & $0.8 \pm 0.02^{\mathrm{a}}$ & $2.5 \pm 0.25^{\mathrm{b}}$ & $0.5 \pm 0.38^{\mathrm{a}}$ & $0.9 \pm 0.13^{\mathrm{a}}$ \\
\hline $\mathrm{C} 24: 0$ & $0.6 \pm 0.03^{\mathrm{a}}$ & $0.4 \pm 0.10^{\mathrm{a}}$ & $0.5 \pm 0.32^{\mathrm{a}}$ & $0.7 \pm 0.03^{\mathrm{a}}$ \\
\hline Total sat. $^{3}$ & $35.8 \pm 1.83^{\mathrm{a}}$ & $38.7 \pm 1.05^{\mathrm{b}}$ & $40.2 \pm 1.58^{c}$ & $37.2 \pm 0.88^{b}$ \\
\hline C16:1n-7 & $7.9 \pm 0.38^{\mathrm{a}}$ & $12.1 \pm 3.37^{b}$ & $8.2 \pm 0.42^{\mathrm{a}}$ & $8.3 \pm 0.27^{\mathrm{a}}$ \\
\hline C18:1n-9 & $23.7 \pm 1.37^{\mathrm{c}}$ & $15.0 \pm 1.23^{\mathrm{a}}$ & $15.2 \pm 4.34^{\mathrm{a}}$ & $19.6 \pm 0.87^{b}$ \\
\hline C18:1n-7 & $4.0 \pm 0.27^{\mathrm{b}}$ & $3.0 \pm 0.33^{\mathrm{a}}$ & $4.0 \pm 0.77^{\mathrm{b}}$ & $4.3 \pm 0.14^{\mathrm{b}}$ \\
\hline C20:1n-9 & $0.2 \pm 0.01^{\mathrm{a}}$ & $0.3 \pm 0.01^{\mathrm{a}}$ & $0.2 \pm 0.11^{\mathrm{a}}$ & $0.2 \pm 0.01^{\mathrm{a}}$ \\
\hline $\mathrm{C} 22: 1 \mathrm{n}-9$ & $0.4 \pm 0.01^{\mathrm{a}}$ & $1.3 \pm 0.95^{\mathrm{b}}$ & $0.2 \pm 0.09^{\mathrm{a}}$ & $0.4 \pm 0.02^{\mathrm{a}}$ \\
\hline C24:1n-9 & $0.1 \pm 0.01^{\mathrm{a}}$ & 0 & $0.1 \pm 0.05^{\mathrm{a}}$ & $0.1 \pm 0.00^{\mathrm{a}}$ \\
\hline Total mono. ${ }^{4}$ & $36.3 \pm 1.58^{c}$ & $31.7 \pm 0.88^{b}$ & $27.9 \pm 4.64^{\mathrm{a}}$ & $32.8 \pm 1.17^{\mathrm{b}}$ \\
\hline C18:2n-6 & $11.6 \pm 0.28^{\mathrm{b}}$ & $8.4 \pm 0.07^{\mathrm{a}}$ & $10.5 \pm 1.13^{b}$ & $10.3 \pm 0.50^{\mathrm{b}}$ \\
\hline C18:3n-6 & $0.4 \pm 0.26^{\mathrm{a}}$ & $0.2 \pm 0.01^{\mathrm{a}}$ & $0.2 \pm 0.15^{\mathrm{a}}$ & $0.2 \pm 0.01^{\mathrm{a}}$ \\
\hline$C 20: 2 n-6$ & $0.4 \pm 0.11^{\mathrm{a}}$ & $0.3 \pm 0.01^{\mathrm{a}}$ & $0.2 \pm 0.11^{\mathrm{a}}$ & $0.2 \pm 0.01^{\mathrm{a}}$ \\
\hline$C 20: 3 n-6$ & $0.8 \pm 0.06^{\mathrm{a}}$ & $0.6 \pm 0.01^{\mathrm{a}}$ & $0.4 \pm 0.23^{\mathrm{a}}$ & $0.7 \pm 0.01^{\mathrm{a}}$ \\
\hline$C 20: 4 n-6$ & $0.8 \pm 0.22^{\mathrm{a}}$ & $0.4 \pm 0.02^{\mathrm{a}}$ & $0.2 \pm 0.21^{\mathrm{a}}$ & $0.4 \pm 0.01^{\mathrm{a}}$ \\
\hline$C 22: 2 n-6$ & $0.1 \pm 0.03^{\mathrm{a}}$ & $0.5 \pm 0.04^{\mathrm{a}}$ & $0.2 \pm 0.12^{\mathrm{a}}$ & $0.2 \pm 0.07^{\mathrm{a}}$ \\
\hline$C 22: 4 n-6$ & $0.2 \pm 0.02^{\mathrm{a}}$ & $0.1 \pm 0.01^{\mathrm{a}}$ & $0.2 \pm 0.12^{\mathrm{a}}$ & $0.3 \pm 0.04^{\mathrm{a}}$ \\
\hline$C 22: 5 n-6$ & 0 & 0 & 0 & 0 \\
\hline Total $n-6^{5}$ & $14.3 \pm 0.47^{\mathrm{c}}$ & $10.5 \pm 0.06^{\mathrm{a}}$ & $11.9 \pm 1.29^{\mathrm{ab}}$ & $12.3 \pm 0.54^{\mathrm{b}}$ \\
\hline$C 18: 3 n-3$ & $1.2 \pm 0.04^{\mathrm{a}}$ & $1.2 \pm 0.04^{\mathrm{a}}$ & $1.0 \pm 0.52^{\mathrm{a}}$ & $1.5 \pm 0.10^{\mathrm{a}}$ \\
\hline$C 20: 3 n-3$ & $0.8 \pm 0.06^{\mathrm{a}}$ & 0 & $0.1 \pm 0.06^{\mathrm{a}}$ & $0.4 \pm 0.20^{\mathrm{a}}$ \\
\hline $\mathrm{C} 20: 5 n-3$ & $0.4 \pm 0.01^{\mathrm{a}}$ & $0.9 \pm 0.02^{\mathrm{a}}$ & $0.2 \pm 0.15^{\mathrm{a}}$ & $0.6 \pm 0.01^{\mathrm{a}}$ \\
\hline$C 22: 5 n-3$ & $2.1 \pm 0.11^{\mathrm{ab}}$ & $3.1 \pm 0.01^{\mathrm{c}}$ & $1.8 \pm 1.02^{\mathrm{a}}$ & $2.4 \pm 0.13^{b}$ \\
\hline$C 22: 6 n-3$ & $9.0 \pm 0.62^{\mathrm{a}}$ & $13.3 \pm 0.47^{\mathrm{b}}$ & $16.6 \pm 1.43^{c}$ & $12.8 \pm 0.64^{b}$ \\
\hline Total $n-3^{6}$ & $13.5 \pm 0.81^{\mathrm{a}}$ & $18.6 \pm 0.41^{\mathrm{c}}$ & $19.8 \pm 3.08^{c}$ & $17.6 \pm 0.62^{b}$ \\
\hline
\end{tabular}

${ }^{1}$ Values of each group were mean \pm standard error. Values in the same column not sharing common superscripts are significantly different among ploidy and season $(P<0.05)$.

${ }^{2}$ All parameters of each group were measured in May, 2016 for spawning season and January, 2016 for non-spwaning season, respectively.

${ }^{3}$ Total saturated fatty acids.

${ }^{4}$ Total monounsaturated fatty acids.

${ }^{5}$ Total n-6 polyunsaturated fatty acids.

${ }^{6}$ Total n-3 polyunsaturated fatty acids. 
ovary of Far Eastern catfish were higher during spawning than after spawning seasons; meanwhile, 20:5n-3 and 22:6n-3 percentages in ovarian total lipids were similar. $20: 5 n-3,22: 5 n-3$ and $22: 6 n-3$ percentages in the dorsal meat of ayu (Hirano \& Suyama, 1983) and 20:5n-3 percentage in sardine (Gamez-Meza et al., 1999) increase in the spawning season. Huynh et al. (2007) reported that spawning Pacific herring, Clupea harengus pallasi also had significantly higher PUFA content in the organ tissues, particularly in the milt and ovary, and notable DHA having the greatest proportion. Perez et al. (2007) suggested that major fatty acids (16:0, 18:1n-9, 20:5n-3 and 22:6n-3), in gonadal and muscular polar, and neutral lipid in both males and females seabream, Diplodus sargus were increased during pre-spawning to mid-spawning, and declined thereafter. PUFA are necessary for the homeostasis in fish.

The subcutaneous fat layer is located between the dermis and the fascia, and is composed mainly of adipocytes and plays a role of nutrient storage and fat synthesis, heat blockage, and shock absorption. Therefore, induced triploids with higher nutrient storage and lipid synthesis are heavier than diploids and have a much subcutaneous fat contents (Table 1 and Fig. 3). Examples of omega-3 fatty acids include alpha-linolenic acid (ALA), docosahexaenoic acid known as DHA, eicosapentaenoic acid known as EPA, stearidonic acid (SDA), ETA (Eicosatetraenoic acid). Linoleic acid and arachidonic acid are classified as omega-6 fatty acids. It is distributed in the nerve cell membrane and the retina, and plays a role of transferring electric stimulus to the next cell at a rapid rate in the cell membrane. It protects cells in the body, maintains cell structure, and helps smooth metabolism. It also has the effect of inhibiting the formation of blood film, and promoting and strengthening bone formation.

Total fatty acid level of induced triploid Chinese catfish, Clarias fuscus was higher than diploid, and induced triploid at low temperature showed the highest fatty acid levels (Qin et al., 1998). In Table 4, total SFA of induced

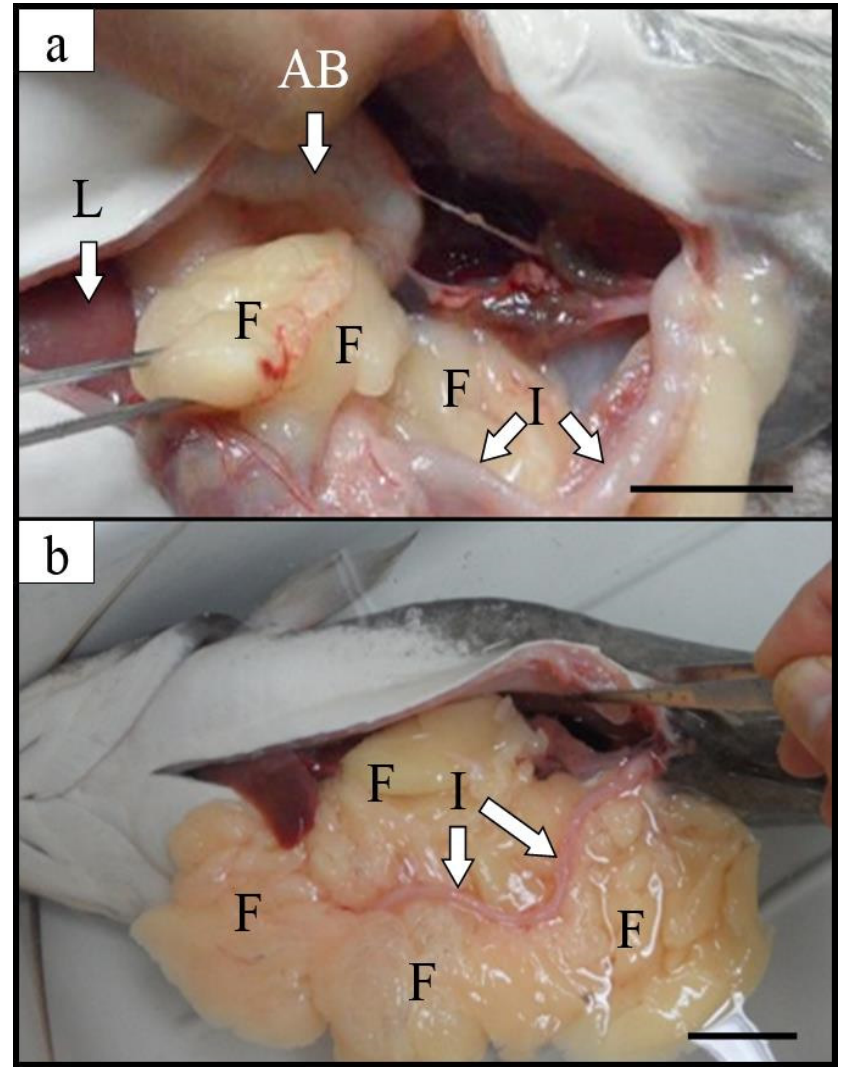

Fig. 3. Internal organs and subcutaneous fat of (a) diploid and (b) induced triploid Far Eastern catfish, Silurus asotus in spawning season. AB: air bladder; F: subcutaneous fat; I: intestine; L: liver. Scale bars indicate $3 \mathrm{~cm}$.

triploid was shown to be higher than diploid, during the spawning season; but during the non-spawning season, diploid appeared to be higher $(P<0.05)$. Total MUFA of diploid was shown to be higher than induced triploid during the spawning season, but during the non-spawning season, induced triploid was shown to be higher $(P<0.05)$. Total n-6 PUFA of diploid was shown to be higher than induced triploid during the spawning season, but during the non-spawning season, induced triploid was shown to be higher $(P<0.05)$. Total n-3 PUFA of induced triploid was shown to be higher than diploid during the spawning season, but during the non-spawning season, diploid was shown to be higher $(P<0.05)$.

As shown in Fig. 4, the total cholesterol of induced tri- 


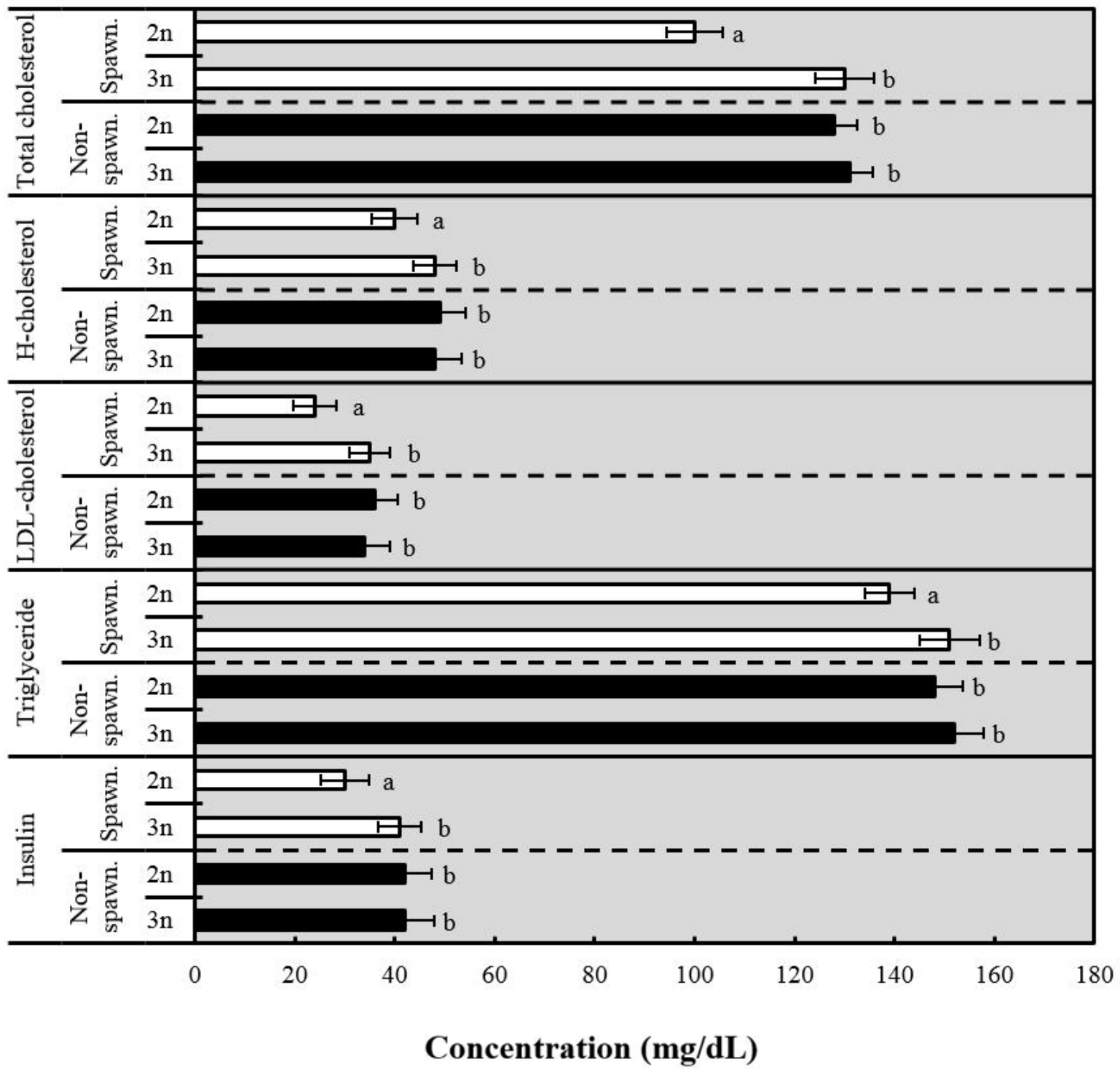

Fig. 4. Comparative analysis of total cholesterol, high cholesterol (H-cholesterol), low density lipoprotein cholesterol (LDL-cholesterol), triglyceride and insulin concentrations between diploid (2n) and induced triploid (3n) Far Eastern catfish, Silurus asotus in spawning (May) and non-spawning season (January) at 2016. The values of horizontal bars are means $\pm \mathrm{SD}(n=30)$ in each group. Different letters on error bars are significantly different for each group $(P<0.05)$.

ploid and diploid Far Eastern catfish showed a significant difference during the spawning season, but there was no significant difference during the non-spawning season $(P<0.05)$. H-cholesterol of induced triploid during the spawning season was shown to be higher, but diploid was higher during the non-spawning season $(P<0.05)$. LDLcholesterol of induced triploid during the spawning season was shown to be higher, but diploid was shown to be higher during the non-spawning season $(P<0.05)$. Triglyceride of induced triploid was shown to be higher during both seasons $(P<0.05)$. Insulin was shown to be higher in induced triploid during the spawning season, but there was no significant difference between diploid and induced triploid during the non-spawning season $(P<0.05)$. 
As it was mentioned by Nobuya et al. (2001), the lipid contents of Far Eastern catfish's ovary during the spawning season were shown to be higher than those during the nonspawning season. In our study, the total lipid acids of induced triploid were shown to be higher than that of the induced triploid, during spawning season. Therefore, higher content of fatty acid in induced triploid will induce higher growth rate of induced triploid. This study revealed the increase in fatty acids of induced triploid, by sterilization in induced triploid.

Thyroid stimulating hormone, thyroxine, total cholesterol, H-cholesterol, LDL-cholesterol, and triglyceride of induced triploid were all shown to be higher than those of diploid, during the spawning season. Thyroid stimulating hormone and thyroxine were related to growth, and three cholesterols and triglyceride were related to the lipidsynthesization. Since the induced triploid is sterile, it is more concentrated on growth and lipid-synthesization, and it converts the energy used in the reproductive system (Kim et al., 1990, 2001; Benfey, 1999). Therefore, the result of this study could be used as evidence of the previous studies about induced triploid fish. Future investigation should be focused on other physiological differences between diploid and induced triploid Far Eastern catfish.

\section{ACKNOWLEDGMENTS}

This research was supported by Basic Science Research Program through the National Research Foundation of Korea (NRF) funded by the Ministry of Science, ICT and Future Planning (NRF-2017R1A2B4005915). We are gratefully thanks to the staff of the Fishery, Genetics Breeding Sciences Laboratory of the Korea Maritime and Ocean University, Korea. This manuscript was outstandingly improved by comments from anonymous reviewers. We declare that all the experiments performed in this study complied with the current laws of Korea (Ordinance of Agriculture, Food and Fisheries, No. 1- the Law Regarding
Experimental Animals, No. 9932) and the Ethical Guidelines of Korea Maritime and Ocean University, Korea.

\section{REFERENCES}

Beatty RA, Fischberg M (1951) Cell number in haploid and polyploid mouse embryos. J Exp Biol 28:541-552.

Benfey TJ (1989) A bibiliography of triploid fish, 1943 to 1988. Can Tech Rep Fish Aquat Sci 1682, p. 33.

Benfey TJ (1999) The physiology and behavior of triploid fishes. Fisher Sci 7:39-67.

Chyung MK (1996) The Fishes of Korea. 5th edition, Ilji Co., Seoul, Korea. pp. 218-219.

Donaldson EM, Fagerlund UHM, Higgs DA, McBride JR (1979) Hormonal enhancement of growth. Fish Physiol. pp. 532-569.

Duncan DB (1955) Multiple range and multiple F tests. Biometrics 11:1-42.

Huyuh MD, Kitts DD, Hu C, Trites AW (2007) Comparison of fatty acid profiles of spawning and non-spawning Pacific herring, Clupea harengus pallasi. Comp Biochem Physiol B 146:504-511.

Ihssen PE, Mckay LR, McMilan I, Philips PB (1990) Ploidy manipulation and gynogenesis in fishes: cytogenesis and fisheries applications. Trans Amer Fisher Soc 119:698-717.

Kim DS, Cho HJ, Park I-S, Choi GC, Nam YK (2001) Cytogenetic traits and gonad development of induced triploidy in far eastern catfish (Silurus asotus). Gene \& Genomics 23:55-62.

Kim DS, Choi GC, JO JY (1990) Induce triploid in channel catfish, Ictalurus punctatus (Teleostomi: Siluriformes). Gene \& Genomics 12:229-235.

Lam TJ, Sharma R (1985) Effects of salinity and thyroxine on laval survival, growth and development in the carp, Cyprinus carpio. Aquaculture 44:201-212.

Lincoln RF, Scott AP (1984). Sexual maturation in triploid rainbow trout, Salmo gairdneri Richardson. J Fish Biol 
25:385-392.

Nobuya S, Suzuki H, Toukairin S, Wada S (2001) Spawning and season affect lipid content and fatty acid composition of ovary and liver in Japanese catfish (Silurus asotus). Comp Biochem Physiol B 129:185-195.

Ojolick EJ, Cusack R, Benfey TJ, Kerr SR (1995) Survival and growth of all-female diploid and triploid rainbow trout (Oncorhynchus mykiss) reared at chronic high temperature. Aquaculture 131:177-187.

Park I-S, Kim DS (2000). Comparison of some tissues in diploid and induced triploid hybrid between mud loach, Misgurnus mizolepis and cyprinid loach, M. anguillicaudatus. Dev Reprod 4:19-28.

Perez MJ, Cejas RJR, Martin MV, Lorenzo SJA (2007) Lipid and fatty acid content in wild white seabream (Diplodus sargus) broodstock at different stages of the reproductive cycle. Comp Biochem Physiol B 146:187196.

Qin JG, Fas AW, Ako H (1998) Growout performance of diploid and triploid Chinese catfish. Clarias fuscus. Aquaculture 166:247-258.

Salem N, Reyzer M, Karanian J (1996) Losses of arachi donic acid in rat liver after alcohol inhalation. Lipids 31:153-156.

Seol DW, Im SY, Hur WJ, Park MO, Kim DS, Jo JY, Park I.-S (2008) Haematological parameters and respiratory function in diploid and triploid Far Eastern catfish, Silurus asotus. Genes \& Genomics 30:205-213.

Shirai N, Hiramitsu S, Toukairin S, Wada S (2001) Spawning and season affect lipid content and fatty acid composition of ovary and liver in Japanese catfish (Silurus asotus). Comp Biochem Physiol B 129:185-195.

Thogaard (1983) Chromosome set manipulation and sex control in fish. Aquaculture pp. 405-434.

Weatherley AH, Gill HS (1987) The Biology of Fish Growth, Influence of Hormones. Academic Press, London. pp. 201-204.

Yang WS, Gil HW, Yoo GY, Park I-S (2015) Identification of skeletal deformities in far eastern catfish, Silurus asotus under indoor aquaculture condition. Dev Reprod 3:153-161.

Yu JY, Park SW, Kim DW (2009) Epithelioma of farmed catfish Silurus asotus in Korea. J Fish Pathol 22:107113. 